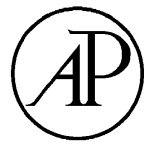

ACADEMIC PRESS
Available online at www.sciencedirect.com

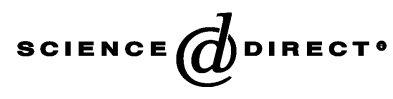

\title{
Federal timber restrictions, interregional spillovers, and the impact on US softwood markets
}

\author{
David N. Wear ${ }^{\mathrm{a}}$ and Brian C. Murray ${ }^{\mathrm{b}, \mathrm{c}, *, 1}$

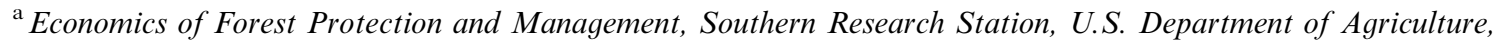 \\ Forest Service, Research Triangle Park, NC, USA \\ ${ }^{\mathrm{b}}$ Environmental and Natural Resource Economics Program, RTI International, Research Triangle Park, NC, USA \\ ${ }^{\mathrm{c}}$ RTI International, 3040 Cornwallis Road, P.O. Box 12194, Research Triangle Park, NC 27709, USA
}

Received 4 June 2001; revised 23 October 2002

\begin{abstract}
An econometric model of the US softwood lumber and timber markets is estimated and used to simulate the price, trade, and welfare effects of reductions in federal timber sales in the western US commencing in the late 1980s. Results indicate that the timber sale reductions increased lumber prices by roughly 15 percent in the mid-1990s. Lumber consumers were the unambiguous losers from the policy, while lumber and timber producers were net welfare gainers as the quantity-induced losses to western lumber producers were more than offset by price increases and quantity gains to southern US and Canadian lumber producers and timber producers in all regions.
\end{abstract}

(C) 2003 Elsevier Inc. All rights reserved.

Keywords: Federal timber policy; Forest preservation; Softwood lumber markets

\section{Introduction}

In a previous article [25], we asserted that federal timber restrictions in the western US, commencing in the late 1980s, were the likely cause of large structural changes in the US lumber market. In that study, we analyzed monthly price series from the two major lumber supply regions in the US, the Pacific Northwest (PNW) and the US South, and found that the degree to which those two regions were linked in a national market for softwood lumber was likely to have been significantly affected by sweeping restrictions on federal timber harvests in the PNW. The

\footnotetext{
${ }^{*}$ Corresponding author. Environmental and Natural Resource Economics Program, RTI International, P.O. Box 12194, Research Triangle Park, NC 27709-2194, USA.

E-mail address: bcm@rti.org (B.C. Murray).

${ }^{1}$ RTI International is a trade name of Research Triangle Institute.
} 
restrictions were driven in part by efforts to protect the habitat of the northern spotted owl on federal lands as mandated by the Endangered Species Act of 1973 (ESA). Although the time-series econometric methods we employed demonstrated strong evidence of structural change in price relationships, their use for hypothesis testing and welfare analysis was limited. For example, the extent to which the federal timber restrictions altered the market is difficult to disentangle from important factors affecting lumber trade between the US and Canada around the same period. Furthermore, reductions in federal timber harvests from the Rocky Mountain states were coincident with changes in the PNW, perhaps confounding impacts. The current paper addresses these shortcomings by developing a structural model of supply and demand to more explicitly test the nature of the structural break and to quantify the policy's price effects and the distribution of welfare effects among the different market participants (i.e., regional producers and consumers) affected by the policy.

Spotted owl protection is one of the most controversial public land issues in US history, the economic ramifications of which may have important implications for the future of the ESA [40]. As shown in Fig. 1, US lumber prices spiked sharply after the restrictions commenced in 19881989 and remained high thereafter. Although there is a strong temptation to assign the price hike exclusively to the spotted owl [25], a report by the Congressional Research Service (CRS) [11] indicates that other factors may have coincided with the spotted owl designation to push up lumber prices. These include momentous changes in US economic activity (a mild recession followed by a protracted recovery) and factors other than the spotted owl that have restricted federal timber harvests in both the PNW and the Intermountain West. To those factors, we add the imposition, then removal, of a tariff on Canadian lumber entering the US. Defensible conclusions on the effects of any one particular policy must take into account all of these relevant factors, which is the objective of this analysis.

A background discussion of the underlying policy issues and related research is provided in the next section and an econometric model is then developed that (1) horizontally links supply regions (including Canadian imports) with aggregate demand for softwood lumber in the US, and

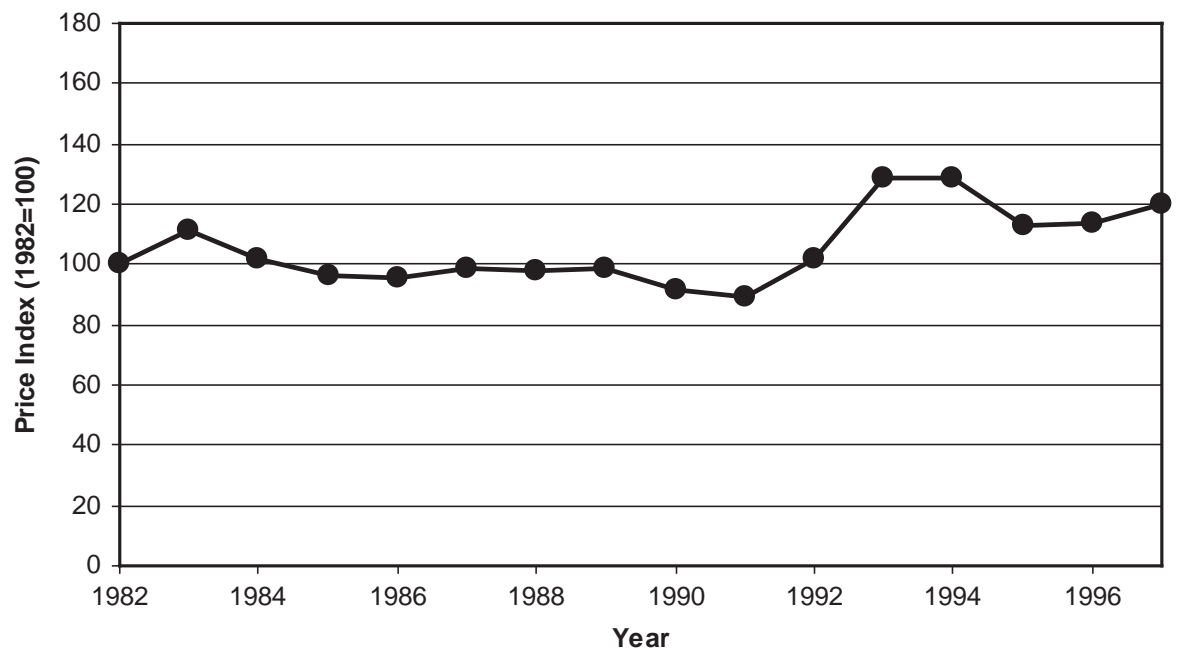

Fig. 1. US Real Lumber Prices: 1982-1997. 
(2) vertically links timber markets to lumber supply in each region. This allows us to jointly estimate the influence of region-specific policy variables, such as federal timber restrictions and tariffs on Canadian lumber on the size and distribution of welfare in the US lumber market. Although the estimation process can be used to test structural hypotheses, its main purpose in this analysis is to simulate aggregate and region-specific price, quantity, and welfare outcomes with and without the federal timber policies imposed. In addition, there is a discussion of the simulation results and the implications for policy.

\section{Background}

In recent years, the geographic composition of the North American softwood lumber industry has changed dramatically. ${ }^{2}$ In the US, softwood lumber production is concentrated in the western and southern regions. Canadian imports are also a significant source of supply to the US market. The western region includes the PNW (Oregon and Washington), California, and the Rocky Mountains states. Most of the region's output has historically come from the PNW. The southern region includes the 12 states in the southeastern-most corner of the US, from Texas to Virginia.

The western US, at one time the dominant producing region in the US lumber industry, has dropped below the US South and Canada in supplying the US market. Western output dropped both relative to other major supply regions and in absolute terms from 1960 to 1995, with a particularly marked drop in the 1990s (see Fig. 2). In 1960, western softwood lumber supplied over 60 percent of US consumption. By 1995, the three major supply regions each accounted for about one-third of the US market. This alteration of trade flows has important implications for laborers and owners of nonlabor factors of production (timber and physical capital) in the forest sector of the different producing regions.

We propose that three primary factors have contributed to the changing composition of the North American softwood lumber industry: interregional trends in forest resources, federal timber policies in the US, and international trade policy between the US and Canada.

\subsection{Interregional trends in forest resources}

Forests, timber growth, and production differ substantially between the western and southern US. The west is dominated by public ownership, with approximately two-thirds of the region's commercially productive timber land managed by the US Forest Service, the federal Bureau of Land Management (BLM), and state departments of natural resources [6]. In contrast, the South's forested landscape is dominated by private owners (90 percent). Roughly 20 percent is held by corporations that own wood-processing facilities, but the large majority is held by nonindustrial entities.

Western harvests have historically come from old-growth forests, particularly in the PNW, although forestry in that region has been shifting from "mining" of old growth to renewable

\footnotetext{
${ }^{2}$ Softwood lumber refers to products made from coniferous tree species such as pine, fir, hemlock, and spruce. In contrast, hardwood lumber is derived from deciduous species such as oak, hickory, and maple. Softwood lumber is used primarily in housing construction and dominates hardwood lumber in terms of overall market volume and value.
} 


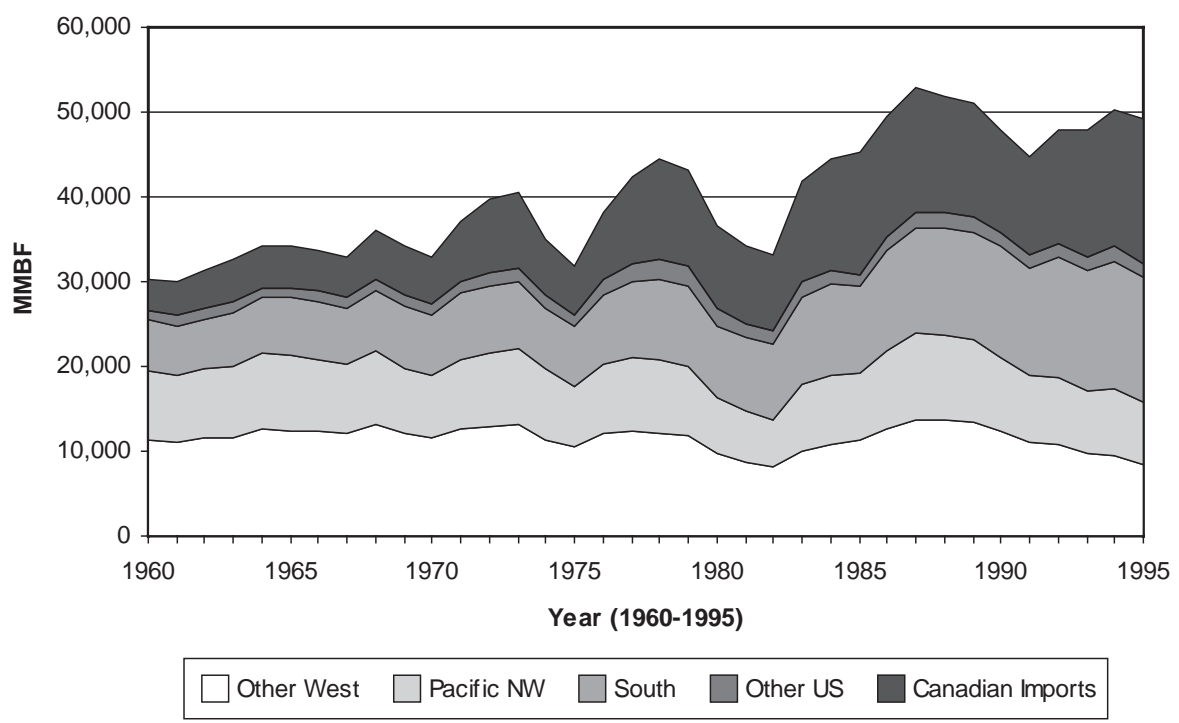

Fig. 2. Lumber Supplied to the US by region.

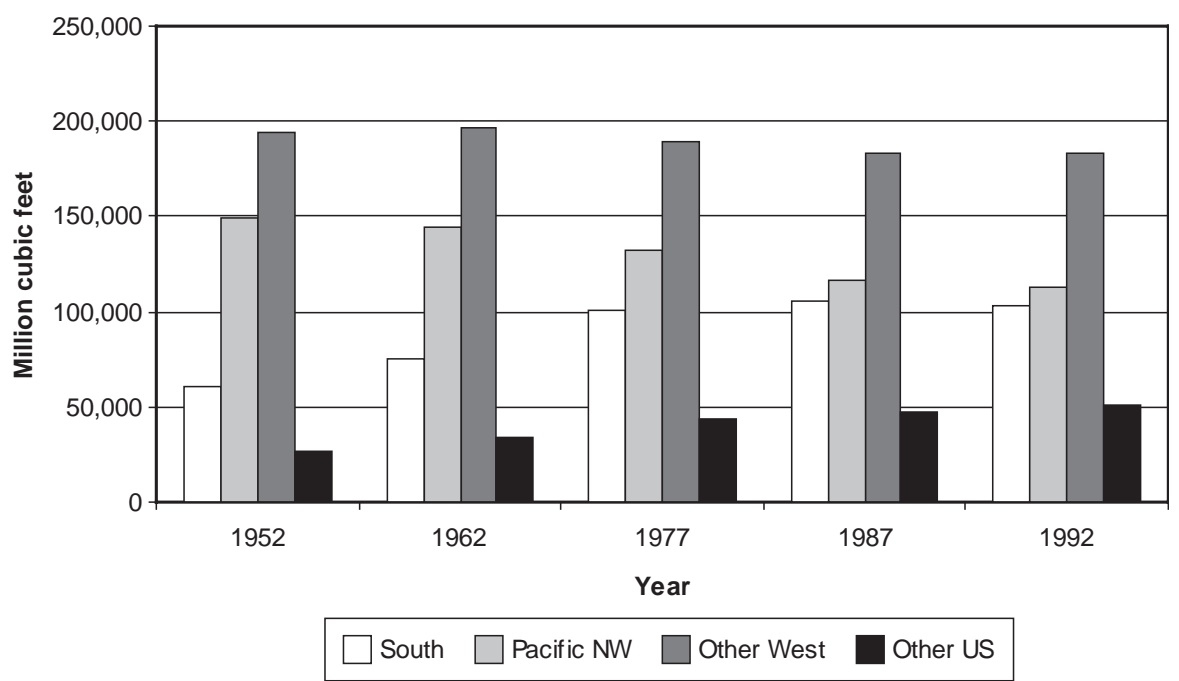

Fig. 3. US Softwood Inventory by region: 1952-1992.

management. In the South, harvests are more frequently and increasingly derived from agricultural forestry, with forests growing on shorter (20- to 30-year) rotations. The shift in lumber production from the west to the south illustrated in Fig. 2 may in part be due to the decline in old growth inventories in the PNW, coupled with the expansion of plantation forestry in the South. The regional trend in softwood inventories is illustrated in Fig. 3. Between 1952 and 1992, softwood inventories declined 24 percent in the PNW and 6 percent in the rest of the west, while rising 70 percent in the south. Southern inventories declined slightly between 1987 and 1992 as a result of increased harvesting activities during that period. 
Although the decline in old growth may have reduced (short-run) lumber production capacity in the PNW from a purely timber stock perspective, its effect on nontimber forest outputs, such as wildlife habitat and aesthetics, may have further reduced timber availability for PNW lumber producers by placing much of the remaining old growth off limits for harvesting.

\subsection{Federal timber policies in the US}

The northern spotted owl was proposed as endangered under the ESA in the Federal Register on June 23, 1989 [13]; final listing came in the Federal Register on June 26, 1990 [14]. To protect the owls, the federal government proposed changes in forest management in 1986, but these changes were immediately challenged as inadequate under the ESA and other resource management statutes. As a result, a federal court enjoined a large share of the national forest timber sale program in the region in 1989 [40]. In February 1992, the BLM was also enjoined from selling timber in designated spotted owl habitat until adequate environmental impact statements were prepared [11]. The federal government responded with a series of administrative studies of various management options followed by judicial contest of those plans. This process culminated on April 2, 1993, with a "Forest Summit," headed by President Clinton and a subsequent federal forest plan. The plan has, to date, passed judicial tests and is being implemented. ${ }^{3}$

Other factors beside the spotted owl designation have reduced federal timber sale offerings. Federal legislation - such as the Wilderness Act of 1964, the Multiple Use Sustained Yield Act (MUSY), and the National Forest Management Act (NFMA) - requires that forest outputs other than timber be given due consideration in the management of national forests. Moreover, agency policies favoring ecosystem management approaches over timber management further reduced federal timber sale offerings in all parts of the country throughout the 1990s. In essence, public demand for nontimber outputs from federal forests has worked its way through a labyrinth of legislative and administrative channels to restrict the amount of federal timber offered for harvest.

Combined, these factors resulted in a significant reduction in timber production from federal (Forest Service and BLM) forests in the west in 1989, which was sustained thereafter (see Fig. 4). Timber sales volumes from western federal forests in 1989 amounted to only 70 percent of sales in 1988. By 1995, timber sales volume dropped to 15 percent of the 1988 level.

\subsection{International trade policy between the US and Canada}

Canada has a strong comparative advantage in the production of softwood lumber. Nearly 80 percent of Canadian lumber production is exported, primarily to the US [26]. Because Canada has a large forest resource from which to draw its timber raw material, has a population that is small relative to the size of the timber resource, and is located close to the large US market for softwood lumber, the country is naturally positioned as a significant exporter of forest products to the US market.

In the mid-1980s, US lumber producers registered a complaint to the Department of Commerce's International Trade Administration (ITA) arguing that the Canadian provincial

\footnotetext{
${ }^{3}$ See Montgomery [24] and Yaffe [40] for detailed descriptions of the chain of administrative and judicial actions in response to the listing of the northern spotted owl.
} 


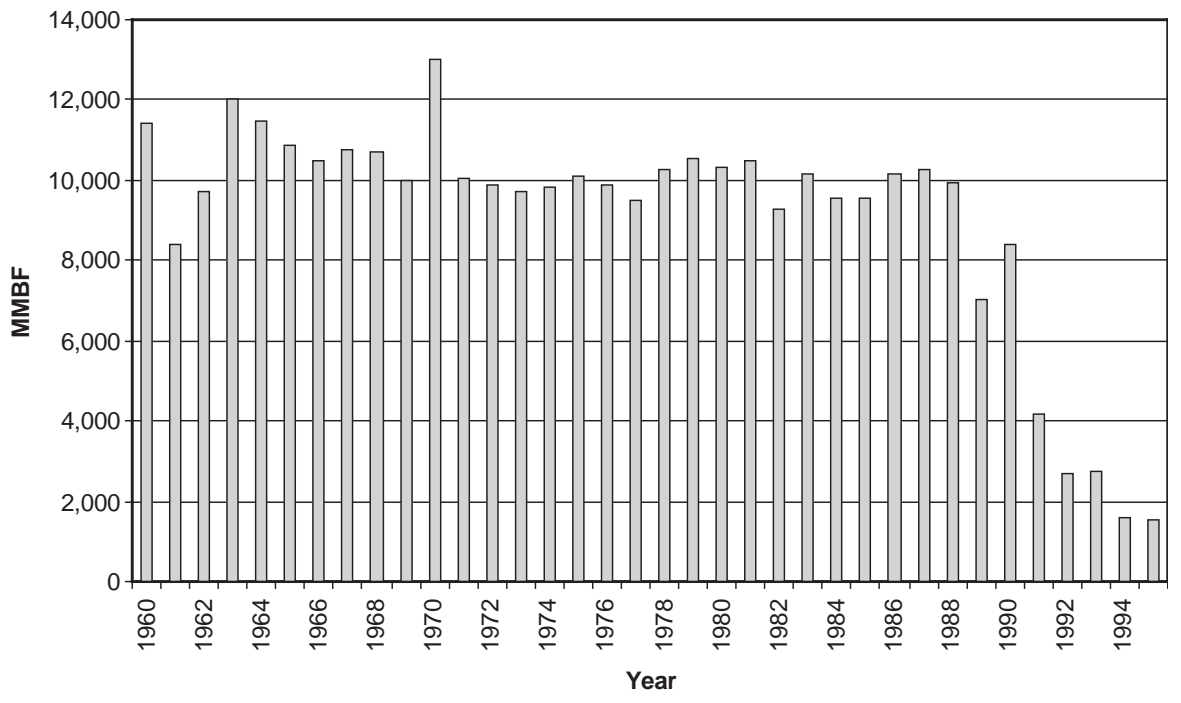

Fig. 4. Federal timber sales-Western US National Forests and BLM land.

governments had collectively subsidized timber sales to Canadian softwood lumber producers, thus constituting anticompetitive trading practices and the "dumping" of Canadian softwood lumber in the US. In late 1986, the ITA ruled in favor of the US lumber industry's complaint. That determination, along with the International Trade Commission's finding that Canada's actions caused injury to US lumber producers, culminated in a trade standoff, wherein the US threatened to impose a 15 percent countervailing duty on all Canadian softwood lumber bound for the US market [39]. Ultimately, the two countries agreed to a Memorandum of Understanding (MOU), wherein Canada imposed an export tariff on softwood lumber shipped to the US. ${ }^{4}$ The MOU persisted until 1991, at which time Canada unilaterally decided not to abide by the agreement. $^{5}$ The export tariff for Canadian lumber was then removed. This issue has continued to attract debate, negotiation, and other controversy between the two countries as the Canadian share of the US market has expanded, as demonstrated in Fig. ${ }^{6}{ }^{6}$

\section{Related research}

Murray and Wear [25] used time-series analysis (e.g., cointegration testing) to find that federal timber restrictions in the PNW strengthened interregional lumber market linkages with the South. Other studies have used time-series methods to test hypotheses regarding the law of one price in

\footnotetext{
${ }^{4}$ The chief difference between the MOU's export tariff and the initial duty threatened by the US was that Canada would collect the tariff revenues rather than the US. The real effect on relative terms of trade was, of course, identical.

${ }^{5}$ The MOU was subsequently amended to account for provincial increases in stumpage prices charged for its timber in lieu of tariffs.

${ }^{6}$ Note that the period covered in this analysis predates the 1996 Canada-US Softwood Lumber Agreement, which imposed a sliding scale of duties on Canadian softwood lumber exports to the US in excess of 14.7 billion BF per year.
} 
US lumber markets [20,34], but they do not examine the corresponding influence of federal timber policies.

Other studies have examined the empirical relationship between the spotted owl-related timber restrictions and forest products markets. As previously noted, the CRS report [11] argues that spotted owl restrictions may have been assigned too much blame for the increase in lumber prices in the early 1990s, but that conclusion does not follow from explicit testing of alternative hypotheses. Since our previous article [25], Rucker et al. [29] have examined lumber price movements to deduce the effect of ESA-induced federal timber restrictions. This paper differs from Rucker et al., as it does from our previous work, by examining the restrictions using a structural supply-demand model rather than time-series analysis of price data.

Several studies have used forest sector projection models to conduct ex ante simulations of the size and distribution of welfare effects caused by the continuation and/or strengthening of the federal timber restrictions in the west. Montgomery et al. [24] used the Timber Assessment Market Model (TAMM) [2] to evaluate the interregional welfare effects of different levels of spotted owl habitat protection, and provided estimates of the marginal cost of successively higher levels of owl protection. A study by Alig et al. [5] used the Forest and Agricultural Sector Optimization Model (FASOM), a dynamic optimization extension of TAMM that captures linkages between the forest and agricultural sectors, to capture interregional effects of continued public timber restrictions, and projected rather extensive welfare transfers from PNW producers to other regional suppliers to the US market. A study by Wagner et al. [37] simulated, jointly, the effects of federal timber restrictions in the western US and private forest practice regulation in the South, and found that these factors would likely raise southern softwood timber prices and, in aggregate, the welfare of southern softwood timber producers.

Several econometric studies have examined the determinants of lumber trade between the US and Canada, with a heavy emphasis on the role of exchange rates $[4,9,30]$ and comparative advantage $[7,18]$. As the US-Canada lumber trade controversy escalated in the mid-1980s but prior to the MOU, two studies examined the welfare effects of potential trade restrictions on Canadian softwood lumber to the US. Boyd and Krutilla [8] used spatial equilibrium market simulations to indicate that welfare effects are highly sensitive to the policy instrument used to constrain trade (tariffs and voluntary restraints) and to the assumed value for export price elasticity. Nyankori and Nodine [27] also evaluated the welfare effects of alternative trade instruments (tariffs, quotas, and domestic subsidies) and found that similar variation of welfare effects across policy options. To our knowledge, Wear and Lee [39] is the only study that examined ex post the welfare effects of the US-Canada MOU and used an analytical model of the Canadian share in the US softwood lumber market to quantify the size and distribution of welfare effects of the MOU as it existed between 1986 and 1991.

In summary, with respect to the current literature, several studies have looked separately at the effects of federal timber restrictions and trade policy, but none has looked at them together as the current analysis does. Moreover, the literature is dominated both by ex ante studies using full market simulation models to project likely outcomes or by ex post studies that look narrowly at specific market processes. In contrast, the current analysis constructs a full econometric model of the US softwood lumber market using data from periods with and without the policy interventions. Using this model allows for testing of the significance of policy effects and simulating market outcomes and welfare measures in their absence. One advantage of this 
approach is the ability to draw a distinction between natural resource policy outcomes based on revealed behavior rather than on predicted responses.

\section{Methods and data}

Our approach to identifying the influence of federal timber supply policies on domestic lumber markets is to estimate models of markets in the presence of these policies and then simulate how markets would have developed without the policies in place. In particular, we apply the following three-step process: (1) estimate an econometric model defining prices and quantities for lumber and timber over a historical period that includes the harvest policies; (2) simulate the evolution of these interrelated markets after removing the influence of the policy (i.e., without harvest reductions from federal forests); and (3) define efficiency, distributional, and spatial (interregional) effects of these policies by comparing scenarios with and without the policy in place.

\subsection{Econometric specification}

The econometric analysis links activity in the final demand market (lumber) with activity in the primary input market (timber). The econometric specification for each sector is presented below.

\subsubsection{US lumber market}

US lumber demand: We assume an aggregate market for US lumber with supply emanating from spatially separated regions. The aggregate annual demand for lumber $\left(L_{\mathrm{D}}\right)$ is defined as

$$
L_{\mathrm{D}}=g_{\mathrm{d}}\left[P_{\mathrm{L}}, P_{\mathrm{S}}, P_{\mathrm{C}}, \mathrm{HS}, \mathrm{RU}, \mathrm{GDP}\right] .
$$

Demand is a function of its own price $\left(P_{\mathrm{L}}\right)$; prices of substitute factors, steel $\left(P_{\mathrm{S}}\right)$ and concrete $\left(P_{\mathrm{C}}\right)$; and end-use factors - housing starts (HS), expenditures for residential upkeep and repair (RU), and gross domestic product (GDP), which proxies for the overall level of economic activity.

Regional US lumber supply: Lumber supply from the three major US regions (south, PNWcoast, and the inland west) is explicitly modeled as follows:

$$
L_{\mathrm{s}}^{i}=g_{\mathrm{s}}^{i}\left[P_{\mathrm{L}}, W_{\mathrm{wp}}^{i}, p_{\mathrm{s}}^{i} ; Z^{i}\right]
$$

where $i$ indexes the south, west coast, and inland west regions. Lumber supply $\left(L_{\mathrm{S}}\right)$ is modeled as a function of its own price $\left(P_{\mathrm{L}}\right)$, wages in the wood products industries $\left(W_{\mathrm{wp}}\right)$, the price of the sawtimber raw material $\left(p_{\mathrm{S}}\right)$, and additional variables $(Z)$ that influence supply in the various regions.

One region-specific factor to consider is the unique role of technical change in southern lumber. Over the period covered by the data, the evolution of pressure-treatment technologies has steadily enhanced the attributes of southern pine lumber relative to softwood lumber from other regions. We capture this technology effect by including a time trend in the supply equation for the South. Theory would also suggest inclusion of a capital stock or rate variable, but such data are not available at a regional level. We assume that this omission does not lead to a serious misspecification given the large share of costs represented by labor and timber in manufacturing 
lumber, and demonstrated mobility of lumber production capacity in the US. For the western regions, $Z$ is the public timber sale volume and serves as a scarcity signal.

Canadian imports: Import of lumber to the US from Canada ( $\left.L_{\mathrm{S}}^{\text {Canada }}\right)$ is modeled implicitly as an excess supply:

$$
L_{\mathrm{s}}^{\text {Canada }}=g_{\mathrm{s}}^{\mathrm{c}}\left[P_{\mathrm{L}}^{\mathrm{R}}, \mathrm{HS}^{\mathrm{c}}, \mathrm{GDP}^{\mathrm{c}}, D_{\mathrm{MOU}}, D_{\mathrm{pMOU}}\right],
$$

where $P_{\mathrm{L}}^{\mathrm{R}}$ is the lumber price multiplied by the real exchange rate, $\mathrm{HS}^{\mathrm{c}}$ is housing starts in Canada, $\mathrm{GDP}^{\mathrm{c}}$ is gross domestic product in Canada, and $D_{\text {mou }}$ is a dummy variable accounting for the influence of the 1987 MOU between the two countries on softwood lumber imports. ${ }^{7} D_{\text {pMou }}$ is a dummy variable accounting for the period following the MOU when the US and Canadian provinces were engaged in lumber trade consultations.

Equilibrium: The lumber market model is completed by the following equilibrium identity:

$$
L_{\mathrm{D}}=L_{\mathrm{S}}^{\text {Inland }}+L_{\mathrm{S}}^{\text {Coast }}+L_{\mathrm{S}}^{\text {South }}+L_{\mathrm{S}}^{\text {Canada }}+L_{\mathrm{S}}^{\mathrm{O}} .
$$

$L_{\mathrm{S}}^{\mathrm{O}}$ is the supply of softwood lumber from the remainder of the US (less than 5 percent of the total) net of a small amount of softwood lumber exports from the US and is treated as an exogenous variable.

\subsubsection{Regional timber markets}

Lumber supply equations contain timber price arguments that are influenced by lumber prices. To correct for endogeneity of timber prices and to set up a mechanism for addressing federal timber supply policies, we explicitly model corresponding regional timber markets in the US Reduced form equations for timber prices are estimated and used to define price instruments for the timber price arguments in lumber supply equations.

Regional timber demand: Derived demand for timber $\left(S_{\mathrm{D}}^{i}\right)$ is from the same production/cost framework that defines the derived supply of lumber:

$$
S_{\mathrm{D}}^{i}=f_{\mathrm{D}}\left[P_{\mathrm{L}}, p_{\mathrm{S}}^{i}, W_{\mathrm{wp}}^{i}\right],
$$

where $i=$ south, west coast, inland west, $P_{\mathrm{L}}$ is the US price of softwood lumber, $p_{\mathrm{S}}$ is the price of timber, and $W_{\mathrm{wp}}$ is the wage rate in the wood products industry.

Regional timber supply: Timber supply is structurally different between the eastern and the western US. In the east, timber production is dominated by private landowners, and supply from western regions is dominated by sale offerings from federal lands. For the south, we model sawtimber supply as follows:

$$
S_{\mathrm{S}}^{\text {South }}=f_{\mathrm{S}}^{\text {South }}\left[p_{\mathrm{S}}^{\text {South }}, p_{\mathrm{p}}^{\text {South }}, I^{\text {South }}, r\right],
$$

where $I^{\text {South }}$ is the volume of private timber inventory contained on private lands in the region, $p_{\mathrm{p}}^{\text {South }}$ is the price of softwood pulpwood (an output substitute for sawtimber), and $r$ is a measure

\footnotetext{
${ }^{7}$ Although the MOU did not take effect until 1987, empirical evidence suggests a substantial anticipatory response in 1986 when a retroactive countervailing duty was a distinct possibility [39]. Thus, the $D_{\text {mou }}$ variable covers the period 1986 through removal of the MOU in 1991. The Wear and Lee study suggests that, even though the structure of the policy instrument changed over this period, the effect - at least on the share of Canadian lumber in the consumption mix-was essentially constant throughout the period.
} 
of the opportunity cost of capital. This formulation - with inventory and capital rates-reflects the dominance of forest capital costs in the production of timber.

In western regions, a large share of supply has been derived from federal timber inventories. Rights to harvest portions of this inventory are sold through timber sales to private sector entities. The amount of this volume under contract to the private sector defines how policy is communicated to wood products markets in western regions. To account for the influence of public timber sales on supply from western regions of the US, we include the volume of public timber under contract (UV) to private interests as an argument in the supply equation [1]. Supply equations are therefore defined as

$$
S_{\mathrm{S}}^{j}=f_{\mathrm{S}}^{j}\left[p_{\mathrm{S}}^{j}, I^{j}, \mathrm{UV}_{\mathrm{NF}}^{j}, \mathrm{UV}_{\mathrm{BLM}}^{j}, r, D_{86}, D_{87}, \mathrm{VS}^{j}\right],
$$

where $j=$ west coast, inland west, $\mathrm{UV}_{\mathrm{NF}}^{j}$ and $\mathrm{UV}_{\mathrm{BLM}}^{j}$ are the uncut volumes under contract in region $j$ from national forests and BLM forests, respectively, and $D_{86}$ and $D_{87}$ are dummy variables that control for the removal of federal timber purchase obligations for private firms in the "buyback" period from 1986 to 1987 under the Federal Contract Payment Modifications Act of 1984 [23]. We also include the level of timber sales in the given year (VS) as a strong anticipatory signal of changes in federal policy regarding timber, which could influence production before being factored through the uncut volume variable. Other variables are as defined before. Although the uncut volume is monitored by the national forests, it is unavailable for BLM lands; thus, we use a 3-year moving average of BLM sales to approximate the uncut volume under contract for BLM lands, $\mathrm{UV}_{\mathrm{BLM}}^{j}$. BLM sales are a significant factor in the coast region but account for less than 2 percent of federal timber harvests in the inland west. ${ }^{8}$ Therefore, we consider only national forest timber sales in the inland region (i.e., set $U V_{\mathrm{BLM}}^{\text {inland }}=0$ ). The price of pulpwood is not included in the supply function because it is not an important substitute product in the west. Application of market identities allows us to construct reduced-form equations for timber prices in our three domestic timber supply regions. Structural equations for timber markets are desirable, but data for total harvest quantities by region are not available.

Linking our policy instrument, sales of timber from public lands, to these raw material and lumber markets requires accounting for how timber sales as well as harvests adjust the uncut volume under contract. For national forests we apply the following equation to describe this stock adjustment process:

$$
\mathrm{UV}_{\mathrm{NF}_{t}}^{j}=\mathrm{UV}_{\mathrm{NF}_{t-1}}^{j}+\mathrm{VS}_{t}^{j}-h_{t}^{j}\left[\mathrm{VH}_{t}^{j}, D_{86}, D_{87}\right]
$$

where VH is the harvest from volumes under contract. ${ }^{9}$ VS, $D_{86}$ and $D_{87}$ are defined above. Even though volume sold directly augments uncut volume under contract (i.e., it has a coefficient of one), volume harvested enters as a function. This is because, although sold volume is an estimate of the harvestable volume used to calculate uncut volume under contract, the harvest volume is

\footnotetext{
${ }^{8}$ Federal landowners sell the rights to harvest standing timber. Sold timber is typically harvested over a 3- to 5-year period. The relevant supply shifter is therefore the "uncut volume under contract," which is the quantity available for harvest by private firms in a given year.

${ }^{9}$ The UV adjustment process differs between national forest and BLM lands because of the lack of data on BLM harvests. Uncut volume under contract on BLM land evolves through time by readjustment of the 3-year moving average of BLM sales, rather than by the stochastic adjustment process identified in Eq. (8).
} 
the actual measured volume removed from the forest. The volume removed from the uncut volume under contract by a harvest is therefore not exactly equal to the harvest volume. The amount of timber harvested from the uncut volume under contract is influenced by market conditions and the amount of volumes available, which is generally consistent with Adams et al. [1]:

$$
\mathrm{VH}_{t}^{j}=h_{H}^{j}\left[L_{s, t}^{j}, \mathrm{UV}_{\mathrm{NF}_{t-1}}^{j}\right]
$$

Restricting access to public inventories presumably will cause movement of logging to private inventories. Private inventories provide a short-run buffer against federal restrictions, but drawing down private inventories creates scarcity and ultimately a rise in timber prices. By including the public-private inventory dynamics in our model, we can capture the private inventory effects when we use the model to simulate policy scenarios below. We specify the annual change in the two western regions' US private softwood sawtimber inventory as a function of each region's lumber output $(L)$, public harvest levels, and a time-trend variable to account for technological change in lumber production:

$$
I_{t}^{j}=I_{t-1}^{j}+f^{j}\left[L_{s, t}^{j}, \mathrm{VH}_{t}^{j}, t\right] .
$$

Public forests are not a significant source of softwood sawtimber production in the South, so the private inventory adjustment equation is simply a function of lumber production and a time trend:

$$
I_{t}^{\text {South }}=I_{t-1}^{\text {South }}+g\left[L_{t}^{\text {South }}, t\right] .
$$

\subsection{Estimation and simulation procedures}

Eqs. (1)-(11) were estimated as a system using three-stage least squares. The fitted equations (15 linear equations and 15 unknowns) were then used as the core of a dynamic simulation model. To this core we added equations that calculate producer and consumer surpluses related to the lumber market. The veracity of the simulation model was evaluated using historical simulations and confidence intervals. Fit of the historical forecasts was evaluated using root mean square percent error statistics. We also examined Theil's $U$ statistics, focusing especially on the bias component of the $U$ to screen for bias in the simulated variables. We used these statistics to check the model for sensitivity to the starting point of the simulation.

A Monte Carlo simulation technique was employed to construct variance estimates for all simulation variables [21,28]. We accounted for variation derived from the additive error terms for each of the 15 equations and the distributions of all estimated coefficients. Using the "Model Procedure" in SAS [31], random perturbations of the additive error terms and parameters were modeled on multivariate normal distributions defined by the covariance matrices for the equations and parameters, respectively. For each iteration of the simulation, perturbations of the parameters were used to define the equations and then perturbations of the additive error term for each time step were used to solve the estimated equations and calculate welfare impacts for the complete simulation period. One thousand such iterations were completed, and results were used to approximate the standard deviations for all price, quantity, and welfare variables in each period. 
To evaluate federal timber policy (i.e., substantial harvest reductions starting in 1989), we simulated market activity with timber sales counterfactually held at their 1979-1988 average values for the period 1989-1995. All other exogenous variables are set to their historical values. The effects of the policy are estimated by comparing output from the counterfactual simulation with the baseline simulation. We measured impacts in terms of differences in simulated regional production and US consumption of lumber, regional timber and US lumber prices, and regional producers' surplus and US consumers' surplus derived from lumber markets.

\subsection{Data}

The analysis requires data on variables over a sufficient period of time to both enable econometric analysis and to span the period of policy influences. We obtained annual data from 1960 through 1996 for the variables listed in Table 1.

\section{Results}

Analytical results are presented in Tables 2-7 and are discussed first for the econometric models, then for the simulation models.

\subsection{Econometric estimation results}

The reduced form equations for regional timber prices are presented in Table 2. The models' predictive powers are good, explaining about 90 percent of the variation in regional prices. Although not too much emphasis should be placed on the sign and statistical significance of individual variables in reduced form equations, we note that most variables have a logical directional effect, and nearly half are statistically significant at the 10 percent significance level or better. Of particular note, all inventory variables (private and public) demonstrate their expected negative effect on timber price.

Econometric results for the US lumber model are presented in Table 3. At the summary level, US lumber demand, southern supply, and Canadian import equations explain more variation than the western supply models, perhaps reflecting limitations on capturing all of the episodic disruptions to western supply. Nonetheless, the performance of the western models in identifying structure is reasonably good. All of the model parameters largely conform to theoretical expectations. The lumber price effect is negative in the demand equations and positive in the supply equations, and is highly significant in three cases and moderately significant in the other two. Timber price has the expected negative sign in all three regional lumber supply equations, although with mixed statistical significance. The US/Canada MOU variables in the Canadian import equation have the expected negative sign, but their high standard error renders them statistically insignificant. Results for the inventory adjustment equations ((8)-(11)) conformed with expectations regarding signs but are not reported here. 
Table 1

Variable description and data sources

\begin{tabular}{|c|c|}
\hline Variable & Description \\
\hline$r$ & Interest rate \\
\hline bp & Bid price, national forest timber \\
\hline GDP & Gross domestic product, US \\
\hline $\mathrm{GDP}^{\mathrm{c}}$ & $\begin{array}{l}\text { Gross domestic product, } \\
\text { Canada }\end{array}$ \\
\hline HS & US housing starts \\
\hline $\mathrm{HS}^{\mathrm{c}}$ & Canadian housing starts \\
\hline$I$ & Private softwood inventory \\
\hline$L_{\mathrm{s}}$ & Lumber production \\
\hline$L_{\mathrm{S}}^{\text {Canada }}$ & $\begin{array}{l}\text { Lumber imported to US from } \\
\text { Canada }\end{array}$ \\
\hline$L_{\mathrm{D}}$ & Lumber consumption, US \\
\hline$P_{\mathrm{L}}^{\mathrm{R}}$ & $\begin{array}{l}\text { US lumber price multiplied by } \\
\text { the real exchange rate }\end{array}$ \\
\hline$P_{\mathrm{L}}$ & $\begin{array}{l}\text { Composite price "softwood" } \\
\text { lumber }\end{array}$ \\
\hline$p_{\mathrm{p}}$ & Price of softwood pulpwood \\
\hline
\end{tabular}

Source

Yield on AAA bonds; The Economic Report of the President [12]

Cut and sold reports from the Washington Office of the Forest Service $^{\mathrm{a}}$

The Economic Report of the President [12]

1970-1995, Selected Forestry Statistics Canada 1996; 1960-1969

Canada Yearbook 1969, 1970-1971, 1973 editions.

Total private housing starts, The Economic Report of the President [12]

1970-1995, Selected Forestry Statistics Canada 1996; 1960-1969

Canada Yearbook 1969, 1970-1971, 1973 editions

Data interpolated and extrapolated using benchmark values for 1952, 1962, 1970, 1976, 1986, and 1991. Source: Haynes, Adams, and Mills [16] (growing stock inventory)

1960-1985, Adams et al. [3, Table 18]; 1986-1996 Western Wood Products Association [38, p. 27]

1950-1985 Adams et al. [3, Table 33]; 1986-1995 Western Wood

Products Association [38, p. 30]

1960-1985, Adams et al. [3, Table 38]; 1986-1996 Western Wood

Products Association [38, p. 31]

(Canada dollar/US dollar) rate from The Economic Report of the President [12]; real rate defined as ( $r^{*}$ US-cpi/Canada-cpi)

Producer price index for softwood lumber (series id. wpu0811)

Bureau of Labor Statistics Internet Home Page [10]

Stumpage price for pine pulpwood harvested in Louisiana; State

Severance Tax Records-Ulrich [33] (1950-1985); Internet Home

Page (1986-1996)

$p_{\mathrm{s}} \quad$ Price of softwood sawlogs by region

$\begin{array}{ll}P_{\mathrm{S}} & \text { Steel price } \\ P_{\mathrm{c}} & \text { Concrete price }\end{array}$

RU Expenditures on upkeep and improvements, US

UV Uncut volume under contract

VH National forest volume harvested

VS Federal timber sale volume

South: Stumpage price for pine sawlogs harvested in Louisiana; State Severance Tax Records-Ulrich [35] (1950-1985), Internet Home page (1986-1996)

West Coast: Cut price for sawtimber in Region 6 of the US Forest Service (Oregon and Washington)

Inland West: Cut price for sawtimber in Region 1 of the US Forest Service (Montana and Idaho)

Producer Price Index for Iron and Steel (Series WPU101), Bureau of Labor Statistics Internet Home Page [10]

Producer Price Index for Concrete Ingredients and Related Products (Series WPU132), Bureau of Labor Statistics Internet Home Page [10].

1965-1994 Howard [17]; 1962, 1963 Ulrich [10]; 1995, Census Bureau Web site [35]; 1960, 1961, and 1964, estimated.

National forest: 1977-1995 Report of the Forest Service to Congress [36]; 1960-1977 backcasted based on regressed extrapolation.

$B L M$ : 3-year moving average of timber sales (see VS below)

Cut and Sold reports from the Washington Office of the Forest Service $^{\text {a }}$

National forests: Cut and Sold reports from the Washington Office of the Forest Service ${ }^{\mathrm{a}}$ 
Table 8 (continued)

\begin{tabular}{lll}
\hline Variable & Description & Source \\
\hline & & BLM: 1960-1993. US Department of Interior, Bureau of Land \\
& Management. Public Land Statistics. Washington DC; US \\
& Department of Interior, Bureau of Land Management. 1994-1995. \\
& & Unpublished data provided by Tom Costello, BLM. \\
$W_{\text {wp }}$ & Wage rate - wood products & Average hourly earnings of production workers (series id. EEU \\
$W^{\mathrm{m}}$ & industry & 31240006) Bureau of Labor Statistics Internet Home Page [10] \\
& Wages - manufacturing & Average hourly earnings of production workers in construction \\
& (construction) industry & industry (series id. EEU20000006); Bureau of Labor Statistics \\
& & Internet Home Page [10] \\
\hline
\end{tabular}

${ }^{\text {a }}$ Cut and sold reports were issued from the Timber Management staff of the USDA Forest Service.

\subsection{Simulation results}

Model simulations were run comparing the counterfactual scenario (federal harvests after 1988 maintain their 1979-1988 average values) with the base case (policy-induced drop in federal harvests). The results are discussed first from the perspective of simulation performance and then for economic content.

\subsubsection{Model evaluation}

We used measures of ex post forecast error (root mean square (RMS) error statistics and Theil's $U$-statistic and "proportions of inequality") to select a starting point for the simulations (Tables 4 and 5 present these statistics for our final simulation baseline). ${ }^{10}$ These measures of fit indicated that starting point has an important effect on simulation performance. Simulations started before the trough of the recession in 1982 always underperformed simulations that started after 1982 (i.e., less precision and higher degree of bias for many variables). Accordingly, we evaluated scenarios from a starting point of 1985 .

\subsubsection{Price, quantity, and welfare effects}

In Table 6, the federal timber policies are expressed in terms of their simulated impact on prices and the size and regional distribution of output quantities. All impacts are measured as the difference between simulated baseline (historic) values and counterfactual values (simulated to have occurred if federal harvest levels had stayed at their pre-1989 levels during 1989-1995). Standard errors for each annual estimate are also reported.

Results are evaluated first for the lumber sector. The six lumber variables evaluated for each year from 1989-1995 generate 42 estimates to consider. Of these, 31 estimates are significant at the 80 percent confidence level or better, 21 are significant at the 90 percent confidence level or better, and 10 are significant at the 95 percent confidence level or better. Notable among the 11 estimates

\footnotetext{
${ }^{10}$ Theil's $U$ is a root mean square error (RMSE) statistic scaled to range from 0 to 1 , with 0 indicating perfect fit. The more useful aspect of the statistic is its decompositions into three "proportions of inequality." The bias proportion $\left(U_{\mathrm{m}}\right)$ indicates systematic error, the variance component $\left(U_{\mathrm{s}}\right)$ indicates the performance in replicating variability, and the covariance proportion $\left(U_{\mathrm{c}}\right)$ is defined by the identity $1=U_{\mathrm{m}}+U_{\mathrm{s}}+U_{\mathrm{c}}$. Low RMSE coupled with $U_{\mathrm{m}}$ and $U_{\mathrm{s}}$ close to zero signal strong overall performance that is unbiased and with good replication of the variables' variability.
} 
Table 2

Estimation results for regional timber price reduced-form equations using three-stage least squares ${ }^{\mathrm{a}}$

\begin{tabular}{|c|c|c|c|c|}
\hline & $\begin{array}{l}\text { Parameter } \\
\text { estimate }\end{array}$ & $\begin{array}{l}\text { Approximate } \\
\text { standard error }\end{array}$ & $t$ Value & $\begin{array}{l}\text { Approximate } \\
\operatorname{Pr}>|t|\end{array}$ \\
\hline \multicolumn{5}{|l|}{ South } \\
\hline Intercept & 961.7886 & 525.4 & 1.83 & 0.0782 \\
\hline Private inventory & -0.00875 & 0.00532 & -1.64 & 0.1116 \\
\hline Interest rate & -8.40306 & 3.475 & -2.42 & 0.0226 \\
\hline US lumber price & 0.287107 & 0.1162 & 2.47 & 0.0201 \\
\hline Wages - South & 13.20923 & 13.7405 & 0.96 & 0.3449 \\
\hline Pulpwood price & 3.621507 & 2.0492 & 1.77 & 0.0885 \\
\hline \multicolumn{5}{|l|}{ West coast } \\
\hline Intercept & 520.1534 & 124.2 & 4.19 & 0.0004 \\
\hline Private inventory & -0.0118 & 0.00324 & -3.64 & 0.0014 \\
\hline Interest rate & -1.69189 & 2.745 & -0.62 & 0.5437 \\
\hline US lumber price & 0.503686 & 0.1272 & 3.96 & 0.0006 \\
\hline Wages-Coast & -14.8382 & 9.7281 & -1.53 & 0.1408 \\
\hline Uncut volume under contract & -0.00189 & 0.00179 & -1.06 & 0.3016 \\
\hline 1986 dummy & -14.8516 & 14.0174 & -1.06 & 0.3004 \\
\hline 1987 dummy & -27.784 & 16.0963 & -1.73 & 0.0977 \\
\hline USFS sold & 0.005303 & 0.00577 & 0.92 & 0.3678 \\
\hline BLM sales & -0.01653 & 0.0205 & -0.81 & 0.4284 \\
\hline \multicolumn{5}{|l|}{ Inland west } \\
\hline Intercept & 110.0942 & 86.3013 & 1.28 & 0.2138 \\
\hline Private inventory & -0.00184 & 0.00156 & -1.18 & 0.2486 \\
\hline Interest rate & 1.359467 & 1.2454 & 1.09 & 0.2854 \\
\hline US lumber price & 0.492994 & 0.0518 & 9.52 & $<.0001$ \\
\hline Wages_West & -8.76696 & 3.9755 & -2.21 & 0.0369 \\
\hline Uncut volume under contract & -0.00282 & 0.00119 & -2.37 & 0.0256 \\
\hline 1986 dummy & 5.499284 & 9.0864 & 0.61 & 0.5505 \\
\hline 1987 dummy & -5.53735 & 8.9748 & -0.62 & 0.5428 \\
\hline USFS sold & -0.00063 & 0.00304 & -0.21 & 0.837 \\
\hline \multicolumn{5}{|l|}{ Summary statistics } \\
\hline Equation & & Adj. $R^{2}$ & \multicolumn{2}{|r|}{ Durbin Watson } \\
\hline South & & 0.8500 & \multicolumn{2}{|r|}{1.3307} \\
\hline Coastal west & & 0.8953 & \multicolumn{2}{|r|}{1.8310} \\
\hline Inland west & & 0.8998 & \multicolumn{2}{|r|}{1.8653} \\
\hline
\end{tabular}

${ }^{\mathrm{a}}$ An instrument for the US lumber price is developed in the first stage.

that are insignificant at the 80 percent level are all seven of the estimates for coastal lumber quantity supply. In fact, lumber quantity reductions in the western inland region are generally larger than in the coastal region. This is surprising, given that the federal timber restrictions are typically attributed to controversy surrounding the spotted owl, a coastal species. This result 
Table 3

Estimates of regional supply and US demand equations for softwood lumber

\begin{tabular}{|c|c|c|c|c|}
\hline & Parameter estimate & $\begin{array}{l}\text { Approximate } \\
\text { standard error }\end{array}$ & $t$ Value & Approximate $\operatorname{Pr}>|t|$ \\
\hline \multicolumn{5}{|l|}{ US demand } \\
\hline Intercept & 21626.67 & 4406.4 & 4.91 & $<.0001$ \\
\hline US lumber price & -9.05837 & 5.357 & -1.69 & 0.1024 \\
\hline Expenditures on housing upkeep & 0.13857 & 0.028 & 4.94 & $<.0001$ \\
\hline Housing starts & 6.704539 & 0.8394 & 7.99 & $<.0001$ \\
\hline US real GDP & 3.106808 & 0.446 & 6.97 & $<.0001$ \\
\hline Price concrete & -77.2343 & 54.948 & -1.41 & 0.1712 \\
\hline Price steel & -5.68088 & 39.587 & -0.14 & 0.887 \\
\hline \multicolumn{5}{|l|}{ Supply-South } \\
\hline Intercept & -369.884 & 2034.5 & -0.18 & 0.857 \\
\hline US lumber price & 7.018788 & 2.6013 & 2.7 & 0.0117 \\
\hline Wage & 501.2539 & 271 & 1.85 & 0.0749 \\
\hline Timber price & -2.54692 & 2.8029 & -0.91 & 0.3713 \\
\hline Trend & 281.4551 & 52.8169 & 5.33 & $<.0001$ \\
\hline \multicolumn{5}{|l|}{ Supply_West coast } \\
\hline Intercept & 7110.124 & 3008.2 & 2.36 & 0.0253 \\
\hline US lumber price & 13.77492 & 3.8879 & 3.54 & 0.0014 \\
\hline Wage & -239.625 & 365.4 & -0.66 & 0.5173 \\
\hline Timber price & -11.8269 & 4.9745 & -2.38 & 0.0245 \\
\hline Public timber sale volume & 0.138106 & 0.124 & 1.11 & 0.275 \\
\hline \multicolumn{5}{|l|}{ Supply_Inland west } \\
\hline Intercept & 6738.229 & 3493.2 & 1.93 & 0.0639 \\
\hline US lumber price & 14.53615 & 5.4665 & 2.66 & 0.0128 \\
\hline Wage & 4.956507 & 416.5 & 0.01 & 0.9906 \\
\hline Timber price & -18.0778 & 8.002 & -2.26 & 0.0318 \\
\hline Public timber sale volume & 0.325317 & 0.1557 & 2.09 & 0.0459 \\
\hline \multicolumn{5}{|l|}{ Imports-Canada } \\
\hline Intercept & -5808.3 & 2153.5 & -2.7 & 0.0119 \\
\hline US lumber price & 13.46707 & 3.4145 & 3.94 & 0.0005 \\
\hline MOU dummy & -1124.61 & 799.7 & -1.41 & 0.171 \\
\hline Post MOU dummy & 172.9718 & 994.9 & 0.17 & 0.8633 \\
\hline Canadian housing starts & 0.005863 & 0.00449 & 1.3 & 0.2031 \\
\hline Canada real GDP & 0.024245 & 0.00466 & 5.21 & $<.0001$ \\
\hline \multicolumn{5}{|l|}{ Summary statistics } \\
\hline Equation & \multicolumn{2}{|c|}{ Adj. $R^{2}$} & & Durbin Watson \\
\hline US demand & \multicolumn{2}{|c|}{0.9239} & & 1.4315 \\
\hline Supply_-South & \multicolumn{2}{|c|}{0.9663} & & 2.4364 \\
\hline Supply_Coastal west & \multicolumn{2}{|c|}{0.4637} & & 1.9867 \\
\hline Supply_Inland west & \multicolumn{2}{|c|}{0.6165} & & 1.4950 \\
\hline Imports - Canada & \multicolumn{2}{|c|}{0.9433} & & 1.0315 \\
\hline
\end{tabular}


Table 4

Root mean square error statistics of fit for historical simulations: 1985-1995

\begin{tabular}{lccr}
\hline Variable & Mean \% error & RMS \% error & $R^{2}$ \\
\hline Timber price, south & 17.3087 & 22.3772 & 0.1155 \\
Timber price, west coast & 1.2306 & 9.6008 & 0.7949 \\
Timber price, inland west & 5.0796 & 19.4256 & 0.6836 \\
Lumber price, US & 3.2319 & 12.4707 & 0.2642 \\
Lumber quantity, south & -2.252 & 4.1083 & 0.6511 \\
Lumber quantity, US & -0.7004 & 3.1186 & 0.5579 \\
Lumber quantity, west coast & -3.7928 & 7.436 & 0.5581 \\
Lumber quantity, inland west & 0.875 & 10.66 & 0.6423 \\
Lumber imports, Canada & 3.6054 & 6.6942 & 0.7153 \\
\hline
\end{tabular}

Table 5

Theil forecast error statistics for historical simulations: 1985-1995

\begin{tabular}{|c|c|c|c|c|c|}
\hline Variable & Correlation $(R)$ & $\begin{array}{l}\text { Bias } \\
\left(U_{\mathrm{M}}\right)\end{array}$ & $\begin{array}{l}\text { Variance } \\
\left(U_{\mathrm{S}}\right)\end{array}$ & $\begin{array}{l}\text { Covariance } \\
\left(U_{\mathrm{C}}\right)\end{array}$ & $U$-statistic \\
\hline Timber price, south & 0.780 & 0.550 & 0.020 & 0.430 & 0.096 \\
\hline Timber price, west coast & 0.900 & 0.000 & 0.300 & 0.700 & 0.047 \\
\hline Timber price, inland west & 0.860 & 0.000 & 0.460 & 0.530 & 0.084 \\
\hline Lumber price, US & 0.530 & 0.020 & 0.300 & 0.680 & 0.060 \\
\hline Lumber quantity, south & 0.930 & 0.320 & 0.450 & 0.230 & 0.022 \\
\hline Lumber quantity, US & 0.790 & 0.060 & 0.380 & 0.560 & 0.016 \\
\hline Lumber quantity, west coast & 0.960 & 0.290 & 0.620 & 0.090 & 0.043 \\
\hline Lumber quantity, inland west & 0.980 & 0.010 & 0.940 & 0.060 & 0.049 \\
\hline Lumber imports, Canada & 0.910 & 0.240 & 0.330 & 0.420 & 0.031 \\
\hline
\end{tabular}

suggests that factors other than the spotted owl are reducing production in the west. Moreover, other nonrestricted sources of timber (e.g., private lands) can help diminish the impact on production in the Coast region. But much of the lack of statistical significance in the coastal shock can be attributed to the imprecision of the underlying parameter estimates. We also note that the change in total US lumber consumption is only weakly significantly different from zero (80 percent level), but this can just as well be seen as confirmation of general equilibrium market dynamics at work rather than as an indication of an econometric problem. In essence, substitution of supply from nonrestricted sources makes up for most of the loss in supply in restricted sources, thereby leaving total US consumption changed very little.

To get a sense of annual magnitudes, the discussion focuses on variable estimates for 1992, which is the mid-point of the policy interval and has values that are fairly close to the periodic mean for all variables. The restrictions were estimated to have raised lumber prices about \$35/ MBF per year (about 15 percent) above the (counterfactual) price if pre-1988 federal harvest levels had been maintained. The estimated price effect was as high as $\$ 53 / \mathrm{MBF}$ in 1995 . Regional production shocks include a decline of 695 million $\mathrm{BF} /$ year (6 percent) in the western inland 
Table 6

Simulated changes in lumber and timber prices and quantities with standard errors

\begin{tabular}{|c|c|c|c|c|c|c|}
\hline \multirow[t]{2}{*}{ Year } & \multicolumn{5}{|c|}{ Lumber quantity } & \multirow[b]{2}{*}{ Lumber price } \\
\hline & US total & South & Coast & Inland west & Canada & \\
\hline \multirow[t]{2}{*}{1989} & -81.996 & 59.185 & -177.741 & -101.87 & 138.431 & 10.2308 \\
\hline & 85.377 & 52.562 & 225.025 & $66.451^{*}$ & 109.852 & 8.6169 \\
\hline \multirow[t]{2}{*}{1990} & -89.518 & 63.228 & -94.917 & -205.46 & 147.635 & 11.0604 \\
\hline & $68.186^{*}$ & $38.286^{* *}$ & 105.983 & $89.832^{* * *}$ & $74.145^{* * *}$ & $6.7104^{* *}$ \\
\hline \multirow[t]{2}{*}{1991} & -277.415 & 195.247 & -143.548 & -772.27 & 443.161 & 34.2239 \\
\hline & $213.799^{*}$ & $119.937^{*}$ & 285.465 & $321.597^{* * *}$ & $227.284^{* *}$ & $20.8576^{*}$ \\
\hline \multirow[t]{2}{*}{1992} & -314.748 & 222.078 & -380.569 & -694.56 & 538.299 & 38.8655 \\
\hline & $244.295^{*}$ & $138.666^{*}$ & 431.142 & $293.91^{* * *}$ & $279.206^{* *}$ & $23.4237^{* *}$ \\
\hline \multirow[t]{2}{*}{1993} & -336.395 & 236.074 & -451.322 & -741.12 & 619.976 & 41.4527 \\
\hline & $253.278^{*}$ & $141.748^{* *}$ & 445.238 & $309.038^{* * *}$ & $302.2^{* * *}$ & $24.0112^{* *}$ \\
\hline \multirow[t]{2}{*}{1994} & -405.898 & 283.09 & -470.764 & -1025.5 & 807.277 & 49.8767 \\
\hline & $298.763^{*}$ & $164.714^{* *}$ & 480.498 & $410.697^{* * *}$ & $373.389^{* * *}$ & $28.0245^{* *}$ \\
\hline \multirow[t]{3}{*}{1995} & -432.945 & 299.95 & -481.233 & -1122 & 870.336 & 53.1878 \\
\hline & $315.795^{*}$ & $172.151^{* *}$ & 486.927 & $443.121^{* * *}$ & $393.303^{* * *}$ & $30.2506^{* *}$ \\
\hline & Timber qua & and price & & & & \\
\hline \multirow[t]{2}{*}{ Year } & South & & West coas & & Inland west & \\
\hline & Quantity & Price & Quantity & Price & Quantity & Price \\
\hline \multirow[t]{2}{*}{1989} & 43.201 & 3.1996 & -127.871 & 0.4159 & -78.362 & 6.3056 \\
\hline & 38.367 & 3.1947 & 161.889 & 12.3402 & 51.116 & $4.3422^{*}$ \\
\hline \multirow[t]{2}{*}{1990} & 46.152 & 3.6288 & -68.285 & 8.2446 & -158.05 & 8.2685 \\
\hline & $27.946^{* *}$ & 2.8636 & 76.247 & 6.6123 & $69.102^{* * *}$ & $3.5473^{* * *}$ \\
\hline \multirow[t]{2}{*}{1991} & 142.516 & 11.0758 & -103.272 & 16.1714 & -594.057 & 26.195 \\
\hline & $87.545^{*}$ & 8.803 & 205.37 & 17.9433 & $247.383^{* * *}$ & $11.4642^{* * *}$ \\
\hline \multirow[t]{2}{*}{1992} & 162.101 & 13.0369 & -273.79 & 25.7636 & -534.274 & 31.799 \\
\hline & $101.216^{*}$ & $10.0704^{*}$ & 310.174 & 25.0394 & $226.084^{* * *}$ & $12.3996^{* * *}$ \\
\hline \multirow[t]{2}{*}{1993} & 172.317 & 14.4337 & -324.692 & 35.6528 & -570.094 & 36.0953 \\
\hline & $103.466^{* *}$ & $10.7235^{*}$ & 320.315 & $27.5104^{*}$ & $237.721^{* * *}$ & $13.0108^{* * *}$ \\
\hline \multirow[t]{2}{*}{1994} & 206.635 & 17.6953 & -338.679 & 42.9113 & -788.847 & 45.0228 \\
\hline & $120.229^{* *}$ & $12.8155^{*}$ & 345.682 & $30.2833^{*}$ & $315.921^{* * *}$ & $15.6289^{* * * *}$ \\
\hline \multirow[t]{2}{*}{1995} & 218.942 & 19.4804 & -346.211 & 47.339 & -863.076 & 50.5433 \\
\hline & $125.658^{* *}$ & $14.0628^{*}$ & 350.307 & $32.4582^{*}$ & $340.862^{* * *}$ & $17.2421^{* * * *}$ \\
\hline
\end{tabular}

Significance levels: ${ }^{*}-p=0.2,{ }^{* *}-p=0.1,{ }^{* * *}-p=0.05,{ }^{* * *}-p=0.01$.

region. Meanwhile the simulated average increase in production from the South is about 220 million $\mathrm{BF} / \mathrm{yr}$ ( 2 percent) as a result of the federal restrictions, and Canadian imports are estimated to have risen by about 540 million $\mathrm{BF} / \mathrm{yr}$ (4 percent). Though regional shifts in supply are not trivial, the estimated average decline in total US lumber consumption is, as indicated above, quite small.

Timber market variables are also presented in Table 6 . The modeling system simulates values for the regional timber price. Canadian timber price effects were excluded because of a lack of 
data. Timber quantity effects were estimated by taking region-specific ratios for the volume of timber to lumber [3] and multiplying by the simulated regional lumber quantities. Thus, regional timber quantity effects are assumed proportionally equal to regional lumber quantity effects. Timber markets' price effects vary significantly by region. The price effect is larger in the inland region $(\$ 32 / \mathrm{MBF}, 43$ percent above counterfactual) than in the Coast $(\$ 26 / \mathrm{MBF}, 15$ percent) and the South $(\$ 13 / \mathrm{MBF}, 5$ percent). Effects in the latter two regions are only marginally statistically significant.

Welfare estimates for the restrictions are presented in Table 7. Lumber producer welfare is measured by integrating over the econometrically estimated supply functions for each region; lumber consumer welfare is estimated by integrating over the US demand function. The welfare of timber demanders (lumber producers) is captured by the lumber producer welfare measures. Estimating timber producer surplus is complicated by the fact that we do not have structural equation estimates of the regional timber supply functions. Timber producer surplus effects are approximated for the South by taking the simulated change in the equilibrium timber prices and quantities for the South and computing a linearized estimate: $\Delta P S=\Delta P\left(S_{0}\right)+0.5(\Delta P)(\Delta S)$, where $\Delta P$ is the change in timber price, $\Delta S$ is the change in timber quantity, and $S_{0}$ is the counterfactual quantity of timber supplied from the South. By using this method, we implicitly assume changes in the South's equilibrium timber prices and quantity brought about by the western federal timber restrictions are occurring via movement along a stable, well-defined neoclassical supply function for the South. This assumption is not tenable for measuring producer surplus for the western regions because the dominance of federal supplies in the west undermines the neoclassical supply assumption, and the regional supply function obviously experiences substantial shifting due to the restrictions themselves. Therefore, to proxy for timber producer surplus effects, we take the change in timber revenues for each western region and multiply it by the ratio of the change in producer surplus in the South ( $\triangle P S$ defined above) to the change in timber revenue for the South. Although imperfect, this gives us a first-order estimate of the net welfare effects on western timber producers (private and public).

The combined welfare effects for the lumber and timber sectors are presented in Table 7. The brunt of the impact is borne by consumers of lumber, who experience annual welfare losses in the neighborhood of $\$ 1.8$ billion (1992). This is about one-eighth of the total annual value of lumber shipments in the US. On the lumber supply side, western producers' surplus effects are relatively small (\$35-\$65 million in 1992) and not statistically different from zero. These losses are relatively small, because rising prices largely compensate for declining output. Restrictions in the western US cause a rise in welfare for southern and Canadian lumber producers of about $\$ 500$ million and $\$ 560$ million, respectively. Taken together, the net impact on domestic lumber producers is positive at about $\$ 600 \mathrm{MM}$ per year, but the simulated standard errors are relatively high, rendering the estimate statistically insignificant. The impact on timber producers is uniformly positive across regions, though not always significant. Southern timber producers gain about $\$ 160 \mathrm{MM} /$ year in surplus, due to both higher prices and output. The western producers also experience net gains of \$230 MM (inland) to \$95 MM (coast), though the latter is not significant. Taking all domestic producer and consumer impacts together, the average annual social cost of the federal timber restrictions for the US is approximately $\$ 1.2$ billion in 1992 . 
Table 7

Change in consumer and producer surpluses for lumber market with standard errors

\begin{tabular}{|c|c|c|c|c|c|c|c|c|c|c|c|}
\hline \multirow[b]{2}{*}{ Year } & \multicolumn{2}{|l|}{ South } & \multicolumn{2}{|l|}{ Coast } & \multicolumn{2}{|l|}{ Inland } & \multicolumn{2}{|c|}{$\begin{array}{l}\text { Total US producer } \\
\text { surplus }\end{array}$} & \multirow{2}{*}{$\begin{array}{l}\text { Consumer } \\
\text { surplus }\end{array}$} & \multirow{2}{*}{$\begin{array}{l}\text { Net } \\
\text { Domestic } \\
\text { Welfare }\end{array}$} & \multirow{2}{*}{$\begin{array}{l}\text { Canada } \\
\text { Lumber PS }\end{array}$} \\
\hline & Timber PS & Lumber PS & Timber PS & Lumber PS & Timber PS & Lumber PS & Timber PS & Lumber PS & & & \\
\hline \multirow[t]{2}{*}{1989} & 38,596 & 126,709 & $-22,002$ & $-18,507$ & 50,896 & 41,633 & 67,490 & 149,836 & $-474,396$ & $-324,560$ & 149,081 \\
\hline & 35,549 & 107,023 & 66,864 & 76,852 & 44,040 & 91,080 & 112,492 & 184,287 & 400,638 & 266,253 & 126,057 \\
\hline \multirow[t]{2}{*}{1990} & 44,413 & 13 & 37,126 & 110 & 59,309 & 9,168 & 140, & 160 & -50 & & \\
\hline & $30,743^{*}$ & $83,976^{* *}$ & 39,024 & 54,266 & $34,334^{* *}$ & 78,424 & $83,192^{* *}$ & 167,451 & $308,694^{*}$ & $198,799^{* *}$ & $97,439^{*}$ \\
\hline \multirow[t]{2}{*}{1991} & 135,355 & 434,437 & 75,495 & 97,847 & 175,652 & 13,287 & 386,502 & 545,570 & $-1,495,731$ & $-950,161$ & 427,447 \\
\hline & $93,723^{*}$ & $267,690^{*}$ & 100,092 & 178,027 & $114,937^{*}$ & 281,492 & $254,051^{*}$ & 597,559 & $920,477^{*}$ & $541,678^{* *}$ & $267,209^{*}$ \\
\hline \multirow[t]{2}{*}{1992} & 164,1 & 50 & 94,391 & 33,83 & 227,544 & 65,424 & 486 , & 602,698 & $-1,786,716$ & $-1,18$ & 560,221 \\
\hline & $112,696^{*}$ & $311,698^{*}$ & 134,446 & 213,569 & $126,337^{* *}$ & 299,976 & $291,844^{* *}$ & 645,079 & $1,084,541^{* *}$ & $685,741^{* *}$ & $345,882^{*}$ \\
\hline \multirow[t]{2}{*}{1993} & 18 & 5 & 138 & 8,590 & 254 & 43,702 & 578 & & -1 , & -1, & \\
\hline & $124,280^{*}$ & $330,149^{* *}$ & 152,485 & 215,404 & $132,929^{* *}$ & 298,990 & $311,556^{* *}$ & 637,796 & 1,135 & $743,348^{* *}$ & $382,359^{* *}$ \\
\hline \multirow[t]{2}{*}{1994} & 233,872 & 682,608 & 173,745 & 6,902 & 285,525 & $-51,666$ & 693,141 & 637,843 & $-2,433,585$ & $-1,795,741$ & 868,158 \\
\hline & $155,556^{*}$ & $396,491^{* *}$ & 172,796 & 240,972 & $153,766^{* *}$ & 335,148 & $361,591^{* *}$ & 690,704 & $1,383,210^{* *}$ & $969,581^{* *}$ & $502,221^{* *}$ \\
\hline \multirow[t]{2}{*}{1995} & 251,605 & 728,284 & 194,331 & 54,095 & 328,531 & 9,933 & 774 & 792,312 & $-2,560,586$ & $-1,768,274$ & 881,684 \\
\hline & $163,103^{*}$ & $427,725^{* *}$ & 204,220 & 406,885 & $207,491^{*}$ & 543,257 & $454,992^{* *}$ & $1,172,878$ & $1,484,698^{* *}$ & $951,410^{* *}$ & $477,525^{* *}$ \\
\hline
\end{tabular}

Significance levels: ${ }^{*}-p=0.2,{ }^{* *}-p=0.1$. 


\section{Summary, policy implications, and conclusions}

The late 1980s and 1990s ushered in a period of rapidly increasing lumber prices and substantial shifts in regional lumber supply within the North American market. There has been much controversy about the extent to which these changes are attributable to timber sale restrictions on federal forests in the US, trade policy between the US and Canada, relative abundance of timber resources across regions, general macroeconomic conditions, or some combination of the above. This paper attempts to resolve some of these issues by estimating a model of the US lumber and timber markets using data that span the periods across which these events occurred. The model is then used to simulate market outcomes without the federal timber restrictions in place to determine the extent to which these policies affected lumber and timber prices and quantities, imports from Canada, and consumer and producer welfare.

Simulation of counterfactual scenarios indicates that the federal timber sales restrictions account for a reallocation among North American producing regions, expanding the market share of the US South and Canada at the expense of producers from the US PNW and inland west. Our findings reinforce the importance of general equilibrium effects in mitigating the economic effects of federal timber harvest restrictions in the west. Surprisingly, the simulation model indicates that the lumber and timber quantity reductions and corresponding timber price effects were statistically insignificant on the West Coast - the home of the spotted owl-after the federal restrictions were put in place. On the other hand, significant reductions and price effects are found for the inland west, which is outside the spotted owl habitat area. This demonstrates that federal timber restrictions commencing in the late 1980s affected all regions dependent on federal timber, not just the old growth forests of the PNW. Moreover, the results confirm findings from our previous study that the western and southern supply regions are tightly integrated into a single national softwood lumber market [25].

The estimate of aggregate domestic welfare costs of the federal restrictions was over $\$ 1.0$ billion per year over most years in the period analyzed. This amounts to approximately $\$ 10$ per US household per year and accounts for 7 percent of the value of total US lumber consumption. Most of the welfare burden is borne by lumber consumers. The negative impact on western lumber producers of reduced output was essentially offset by the corresponding rise in price, leading to a statistically insignificant net change in producer surplus for western producers. Moreover lumber producers from other regions (US South and Canada) reaped windfall gains as their prices rose without a corresponding constraint on their supply. The same is true for private timber suppliers, whose aggregate welfare gains are estimated to be positive at a 90 percent confidence level or better for most years in the interval. Thus, on balance, the net effect of the timber restrictions on forest products producers appears to have been positive. In contrast to the federal timber restrictions, results of the current study suggest that the US-Canadian lumber trade barriers had a relatively small impact on the US lumber market during the period of analysis.

These social costs, of course, are only part of the story. The federal timber restrictions left undisturbed large forest areas that would have otherwise been harvested. These forests provide critical habitat not only for the spotted owl, but other species, threatened or not, and produce other nontimber services that society values. We make no attempt here to estimate those values, but a contingent valuation study by Hagen et al. [15] suggests that the preservation benefits aggregated across all US households may be larger than the welfare costs estimated here. Further 
Table 8

Leakage effects ${ }^{\mathrm{a}}$

\begin{tabular}{lrl}
\hline Public harvest timber reductions & & \\
$\quad$ West coast & 1200.4 & \\
Inland west & 866.8 & \\
Total west & 2067.2 & Percent leakage $^{\mathrm{b}}$ \\
& & $43.3 \%$ \\
Induced harvests elsewhere & 894.6 & \\
Western private lands & 298.9 & $57.7 \%$ \\
South & 1193.5 & $84.4 \%$ \\
US total & 550.4 & \\
Canada & 1744.0 & \\
North America total &
\end{tabular}

${ }^{a}$ All quantities are in million board feet, timber scale (1990-1995 annual average).

${ }^{\mathrm{b}}$ Leakage $=$ Induced harvest in area $i$ divided by total west public harvest reduction.

review of this and other related benefits studies is necessary to determine whether the federal restrictions were, on balance, welfare enhancing.

Our findings also provide insights into a broader class of problems involving forest preservation. The central question is to what degree will harvest restrictions or forest preservation in one region be offset by market-driven compensatory harvesting in other regions. For example, this result, often called "leakage," is central to proposed policies for using forest stocks to sequester $\mathrm{CO}_{2}$ from the atmosphere, thereby mitigating climate change [19]. If we viewed the federal timber restrictions analyzed in this paper as if they were enacted as climate policy-to be clear, they were not - one might ask the extent to which leakage eroded the policy's benefits. Table 8 provides some empirical evidence. The average annual federal timber harvest reduction (below the projected baseline) in the US West for the period 1990-1995 was approximately 2.1 billion board feet. However, private harvests in the west were estimated to have risen by 895 million board feet in response. Thus, just within the region, the leakage factor - the percentage of induced harvests divided by the first-order reduction - was about 43 percent. The leakage effect increases when the geographic scale is expanded. Taking into consideration the approximately 300 million board feet annual private harvest response in the South, the total US offsetting harvests is nearly 1.2 billion board feet, or a 58 percent leakage factor. Finally, the policy is estimated to have increased Canadian timber harvests by 550 million board feet. Taken together, the federal harvest reductions of 2.1 billion board feet in the US West produced more than a 1.7 billion board feet harvest increase in softwood production elsewhere in North America. Thus, harvest leakage at a continental scale was on the order of 84 percent.

The findings here demonstrate one recurring theme in natural resource policy: resource restrictions in one place tend to move extractive activity to other places. For instance, since the late 1980s softwood harvest removals have approached and even exceeded the growth rate in parts of the Southeastern US [32]. Likewise, concerns regarding the sustainability of Canadian harvests have emerged [22]. Thus, measures to protect habitat in the western US may have caused a degradation of habitat and other ecological services provided by forests in other places. Therein lies the complexity of coordinating local, regional, and national environmental goals through the policy process. 


\section{References}

[1] D.M. Adams, C.S. Binkley, P.A. Cardellichio, Is the level of national forest timber harvest sensitive to price?, Land Econ. 67 (1991) 74-84.

[2] D.M. Adams, R.W. Haynes, The 1980 Softwood Timber Assessment Market Model: Structure, Projections, and Policy Simulations, Forest Science Monograph no. 22, 1980.

[3] D.M. Adams, K.C. Jackson, R.W. Haynes, Production, consumption, and prices of softwood products in North America: regional time series data, 1950 to 1985, USDA Forests Service, Res. Bull. PNW-RB-151, Portland OR, 1988.

[4] D.M. Adams, B. McCarl, L. Hamayounfarrokh, The role of exchange rates in Canadian-United States lumber trade, Forest Sci. 32 (1986) 973-988.

[5] R.J. Alig, D.M. Adams, B.A. McCarl, Impacts of incorporating land exchanges between forestry and agriculture in sector models, J. Agr. Appl. Econ. 30 (2) (1998) 389-401.

[6] R.J. Alig, W.G. Hohenstein, B.C. Murray, R.G. Haight, Changes in area of timberland in the United States, 1952-2040, by ownership, forest type, region, and state, General Technical Report SE-64, Asheville, NC: U.S. Department of Agriculture, Forest Service, Southeastern Forest Experiment Station, 1990.

[7] B. Bonnefoi, J. Buongiorno, Comparative advantage of countries in forest-products trade, Forest Ecol. Manage. 36 (1990) 1-17.

[8] R. Boyd, K. Krutilla, The welfare impacts of U.S. trade restrictions against the Canadian softwood lumber industry: a spatial equilibrium analysis, Can. J. Econ. 20 (1) (1987) 17-35.

[9] J. Buongiorno, J.P. Chavas, J. Uusivuori, Exchange rates, Canadian lumber imports, and United States prices: a time-series analysis, Can. J. Forest Res. 18 (1988) 1587-1594.

[10] Bureau of Labor Statistics, Web site for interactive query of BLS databases; http://stats.bls.gov/datahome.htm.

[11] Congressional Research Service (prepared by Ross W. Gorte), Lumber prices - 1993. Report for Congress, 1994; accessed May 29, 1998, www.cnie.org/nle/for-12.html.

[12] Council of Economic Advisors, Economic Report of the President, U.S. Government Printing Office, Washington DC, 1996.

[13] 54 Federal Register 26666, June 23, 1989.

[14] 55 Federal Register 20821, June 26, 1990.

[15] D.A. Hagen, J.W. Vincent, P.G. Welle, Benefits of preserving old-growth forests and the spotted owl, Contemp. Pol. Issues 10 (1992) 13-26.

[16] R.W. Haynes, D.M. Adams, J.R. Mills, The 1993 RPA Timber Assessment Update, Gen. Tech. Rpt. RM-25, USDA Forest Service, Rocky Mountain Station, 1995.

[17] J.L. Howard, U.S. Timber Production, Trade, Consumption, and Price Statistics 1965-1994, Gen. Tech. Rpt. FPL-GTR-98, USDA Forest Service, Forest Products, Laboratory, 1997.

[18] J.S. Hseu, J. Buongiorno, Price elasticities of substitution between species in the demand of U.S. softwood lumber imports from Canada, Can. J. Forest Res. 23 (1993) 591-597.

[19] Intergovernmental Panel on Climate Change (IPCC), Land Use, Land-Use Change, and Forestry, Cambridge University Press, Cambridge, UK, 2000.

[20] C. Jung, K. Doroodian, The law of one price for U.S. software lumber: a multivariate cointegration test, Forest Sci. 40 (4) (1994) 595-600.

[21] J.S. Liu, Monte Carlo Strategies in Scientific Computing, Springer, New York, 2001.

[22] D.W. MacCleary, Ecological Sustainability, Consumption and NIMBYism: Enlightened Conservation Illuminates Need for a Personal Consumption Ethic, Vol. 9, Number 1, The Woodland Steward, 2000; http://www.fnr.purdue.edu/inwood/past\%20issues/EcologicalSustainability.htm.

[23] J.P. Mattey, The Timber Bubble that Burst, Oxford University Press, New York, 1990.

[24] C.A. Montgomery, G.M. Brown, D.M. Adams, The marginal cost of species preservation, J. Environ. Econ. Manage. 26 (1994) 111-128.

[25] B.C. Murray, D.N. Wear, Federal timber restrictions and interregional arbitrage in U.S. lumber, Land Econ. 74 (1) (1998) 76-91.

[26] Natural Resources Canada, Selected Forestry Statistics Canada 1996 (unpublished), Industry, Economics and Programs Branch, Canadian Forest Service, 1997. 
[27] J.C.O. Nyankori, S.K. Nodine, Implications of restrictions on the imports of Canadian softwood lumber to the southern softwood lumber industry, Rev. Reg. Stud. 17 (1) (1987) 45-52.

[28] R.S. Pindyck, D.L. Rubinfeld, Econometric Models and Economic Forecasts, 4th Edition, McGraw-Hill, New York, 1998.

[29] R.R. Rucker, W.N. Thurman, J.K. Yoder, Estimating the structure of market reaction t news: information events and lumber futures prices, unpublished, February 14, 2002.

[30] R. Sarker, Canadian softwood lumber export to the United States: a cointegrated and error-corrected system, J. Forest Econ. 2 (3) (1996) 205-231.

[31] SAS Institute Inc., SAS/ETS User's Guide, Version 6, 2nd Edition, SAS Institute Inc., Cary, NC, 1993.

[32] W.B. Smith, J.S. Vissage, D.R. Darr, R.M. Sheffield, Forest Resources of the United States, 1997, A Technical Document Supporting the 2000 USDA Forest Service RPA Assessment, St. Paul, MN, U.S. Department of Agriculture, Forest Service, 2002.

[33] A.H. Ulrich, U.S. Timber Production, Trade, Consumption, and Price Statistics 1950-1985, Misc. Publ. no. 1453, USDA Forest Service, Washington, DC, 1987.

[34] N.D. Uri, R. Boyd, Considerations on modeling the market for softwood lumber in the United States, Forest Sci. 36 (3) (1990) 680-692.

[35] U.S. Census Bureau, Web site for interactive query of Census of Housing data; http://www.census.gov/hhes/www/ housing.html.

[36] USDA Forest Service, Various issues, Report of the Forest Service, USDA Forest Service, Washington, DC.

[37] J.E. Wagner, F.W. Cubbage, T.P. Holmes, Estimated economic impacts of environmental regulations on southern softwood stumpage markets, Southern J. Appl. Forestry 18 (4) (1994) 156-162.

[38] Western Wood Products Association, Statistical Yearbook of the Western Lumber Industry, WWPA Unnumbered Publication, 1995.

[39] D.N. Wear, K.J. Lee, U.S. policy and Canadian lumber: effects of the 1986 memorandum of understanding, Forest Sci. 39 (4) (1993) 799-815.

[40] S.L. Yaffe, The Wisdom of the Spotted Owl: Policy Lessons for a New Century, Island Press, Washington, DC, 1994. 